EMPOWER: Jurnal Pengembangan Masyarakat Islam

Vol. 5, No. 2, Desember 2020, hlm. 132-154

e-ISSN: 2580-0973, p-ISSN: 2580-085X

Tersedia online di: http:// syekhnurjati.ac.id/jurnal/index.php/empower

Email: empowerjurnal@gmail.com

\title{
Manajemen Perang Bisnis Dalam Pemikiran Sun Tzu dan Implementasinya terhadap Manajemen Dakwah dalam Pemberdayaan Masyarakat
}

\author{
Syahrul Kirom*
}

(Akidah dan Filsafat Islam, Fakultas Ushuluddin Adab dan Dakwah, IAIN Syekh Nurjati Cirebon)

Email: syahrulkirom1984@gmail.com

\section{Muhammad Ikhsan Ghofur**}

(Pengembangan Masyarakat Islam, Fakultas Ushuluddin Adab dan Dakwah, IAIN Syekh Nurjati Cirebon)

Email: kㅐsan.ghofur@syekhnurjati.ac.id

\section{Article History}

Submitted: 30.09.2020, Revised: 23.10.2020, Accepted: 09.12.2020

\begin{abstract}
Sun Tzu's work on The Art of War inspires many world figures such as Napoleon Bonaparte in applying the art of war strategy. This study used a descriptive-analytical approach with the hermeneutic method. In this paper, the writer tried to interpret the art strategy of war into the world of business.

The results of this study indicate that the manajement of Sun Tzu's arts of war. First, the principle of knowing yourself, in this case know your enemies and yourself, how to preach and empower people to achieve the best goals. Second, regarding moral integrity in preaching and empowering the community. In preaching and empowering people, both professions and consumers, it is expected that they always prioritize the values of honesty and kindness. Third, a brave attitude, in terms of preaching and empowering the community, what is needed is the
\end{abstract}


ethics of courage by being brave in making decisions in the right way. Fourth, discipline in terms of preaching and empowering the community is by always arriving on time, never doing time corruption, but always arriving and right when there is an activity with the community Fifth, welfare needs to be put forward by every preacher in empowering the community by providing services and appreciation to society, that is what is called the ethics of love which always puts forward the human aspect of society or maudhu'.

Thus, Sun Tzu's business war manajement view emphasizes human ethics. Each of the teachings of Sun Tzu's martial arts, when interpreted in preaching and community empowerment, turns out to be more concerned with the area of ethics and morality in achieving success in society.

Key words: ethics, moral integrity, courage

Abstrak
Karya Sun Tzu tentang The Art of War memberikan
inspirasi banyak tokoh-tokoh dunia seperti Napoleon
Bonaparte dalam menerapkan strategi seni perang.
Penelitian ini menggunakan pendekatan deskriptif-analitis.
Dengan Metode Hermeneutika. Dalam tulisan ini, penulis
ingin berusaha menginterpretasikan strategi seni perang ke
dalam dunia bisnis.
Hasil penelitian ini menunjukkan bahwa manajemen seni
perang Sun Tzu. Pertama, Prinsip mengenal diri sendiri,
dalam hal ini kenalilah musuh dan diri anda sendiri,
bagaimana agar dalam berdakwah dan memberdayakan
masyarakat bisa mencapai tujuan yang terbaik. Kedua,
mengenai integritas moral di dalam berdakwah dan
memberdayakan masyarakat. Di dalam berdakwah dan
memberdayakan masyarakat baik sesama profesi maupun
konsumen diharapkan selalu mengedepankan nilai
kejujuran dan kebaikan. Ketiga, sikap berani, dalam hal
berdakwah dan memberdayakan masyarakat yang
dibutuhkan adalah etika keberanian dengan jalan berani
mengambil keputusan-keputusan dengan jalan yang benar.


Keempat, dispilin dalam hal berdakwah dan memberdayakan masyarakat adalah dengan cara selalu datang tepat waktu, tidak pernah melakukan korupsi waktu, melainkan selalu datang dan tepat ketika ada kegiatan dengan masyarakat Kelima, kesejahteraan perlu dikedepankan oleh setiap pendakwah dalam memberdayakan masyarakat dengan cara memberikan pelayanan dan penghargaan kepada masyarakat, itu adalah apa yang disebut sebagai etika kasih yang selalu mengedepankan aspek kemanusiaan terhadap masyarakat atau maudhu'.

Dengan demikian, pandangan manajamen perang bisnis Sun Tzu lebih menekankan pada etika kemanusiaan. Tiaptiap ajaran seni perang Sun Tzu, ketika diintrepretasikan di dalam berdakwah dan pemberdayaan masyarakat, ternyata lebih banyak berkutat pada wilayah etika dan moralitas dalam meraih kesuksesan di masyarakat.

Kata kunci: etika, integritas moral, sikap berani

\section{PENDAHULUAN}

China saat ini menjadi macan Asia dan bahkan di dunia, banyak hal yang telah dilakukan China sehingga mencapai perkembangan kemajuan yang sukses. Kesuksesan Negeri China tak bisa dilepaskan dari Sun Tzu, di mana strategi seni perang dari Sun Tzu banyak digunakan oleh pejabat tinggi China. Melainkan kemajuan di China itu disebabkan juga karena memiliki budaya yang tinggi, mereka sangat menerapkan ajaran-ajaran leluhur seperti confucianisme dan taoisme ${ }^{1}$.

Sun Tzu, menulis dalam karyanya The Art of War yang terdiri dari 7000 aksara pada kira-kira tahun 500 sebelum masehi. The Art of War mungkin salah satu buku yang ditulis pada bilah-bilah bambu, karya yang diakui ini telah meraih reputasi internasional sebagai

1 H.G Creel, Chinese Thought from Confusius to Mao Tse-Tung (Yogyakarta: Tiara Wacana, 1990), 1. 
intisari strategi yang meraih kemenangan. Selama berabad-abad, The Art of War dijunjung tinggi oleh para ahli strategi Tiongkok maupun Jepang, banyak pernyataan Mao diambil dari filosofi Sun Tzu.

The Art of War adalah landasan dari strategi timur. Tesis sentral Sun Tzu adalah bahwa anda bisa menghindari pertempuran kalau anda merencanakan strategi yang tepat sebelum pertempuran. Konsep strategi seni perang dari Sun Tzu itu dapat digunakan dalam hal pemberdayaan masyarakat terutama bagi dai dalam melaksanakan manajemen dakwah. Banyak penelitian sebelumnya tentang pemikiran Sun Tzu, tetapi lebih kepada manajemen bisnis dan ekonomi seperti yang dikaji oleh Ida Bagus yang meneliti dalam bidang manajemen bisnis ${ }^{2}$, penelitian lain yaitu yang dilakukan oleh Agung Budi mengenai akuntansi dan organisasi ${ }^{3}$, dan yang ditulis Arista Fauzi mengenai perbankan syariah terutama dalam akad mudharabah ${ }^{4}$. Oleh karena itu, perlu dikaji lebih mendalam mengenai pemikiran Sun Tzu apabila diimplementasikan terhadap manajemen dakwah dalam pengembangan masyarakat. Sebab apa, Sun Tzu yang juga seorang filosof dan dikenal oleh kalangan akademik, melalui karya-karyanya yang telah memberikan inspirasi banyak orang semakin layak untuk diteliti lebih dalam. Tulisan ini akan mencoba membahas mengenai manajemen dan strategi bisnis menurut Sun Tzu dari karya The art of war dengan memberikan interpetasi dari The Art of War ke dalam pemberdayaan masyarakat dan bagaimana manajemen dan strategi dakwah yang dikedepan. The Art of War telah banyak

2 Ida Bagus Radendra Suastama, "Seni Perang Sun Tzu Tentang Strategi Operasi Dikaitkan Dengan Manajemen Bisnis," in Forum Manajemen STIMI Handayani Denpasar, vol. 9, 2011, 72-75.

3 Agung Budi Sulistiyo, "Antara Seni Berperang Ala Sun Tzu, Akuntansi Dan Sustainabilitas Organisasi," EKUITAS (Jurnal Ekonomi Dan Keuangan) 16, no. 1 (2018): 16-31.

${ }^{4}$ Arista Fauzi Kartika, "FINANCIAL ENGINEERING: Win-Win Solution 'Sun Tzu' Untuk Jaminan Pada Akad Mudharabah," Jurnal Penelitian Teori $\mathcal{E}$ Terapan Akuntansi (PETA) 2, no. 2 (2017): 98-111. 
memberikan ide-ide brillian di dalam semua bidang kehidupan manusia.

Pertanyaan secara filosofis adalah bagaimana pandangan strategi bisnis menurut Sun Tzu? pertanyaan itu sangat penting untuk diajukan guna untuk memahami pemikiran Sun Tzu mengenai manajemen dan strategi bisnis yang bersumber dari The Art of War yang mengandung banyak nilai-nilai filosofis perlu diimplementasikan di dalam pemberdayaan masyarakat Indonesia melalui manajemen dakwah seoarang dai. Metode penelitian dengan menggunakan hermeneutika, caranya adalah dengan berusaha menginterpretasikan kembali pemikiran Sun Tzu tentang strategi perang bisnis, yang kemudian dikaitkan dengan objeknya seperti pada Usaha kecil seperti UMKM, atau Toko titel kecil maupun dalam wiralaba, bahkan lebih besar pada perusahaan, sehingga hasil dari usaha itu dapat meningkatkan ekonomi.

\section{HASIL DAN PEMBAHASAN}

\section{Sejarah Sun Tzu}

Mengenai siapakah Sun Tzu hingga sekarang masih dalam perdebatan, tidak banyak yang tahu pasti siapa Sun Tzu dan dia hidup di zaman perang China apa. Sun Tzu, dilahirkan dengan nama Sun $\mathrm{Wu}$, diperkirakan hidup dari tahun 544 SM sampai 496 SM. Dalam masa hidupnya, dia menuliskan kitab militer yang di rakyat Cina sendiri terkenal dengan nama "Sun Tzu" atau di kalangan orang barat dikenal dengan "The Art of War of Sun Tzu".

Dalam menulis kitab militer Sun Tzu penuh reflektif, dengan sikap yang reflektif, berarti ia menguasa penuh segalanya. Sebab apa yang ditulisanya memikirkan alam semesta dan kepentingan manusia. Hal ini apa yang disebut oleh seorang filsuf Cina Kuno, Hui Shih, sebagai "Yang Maha Agung". ${ }^{5}$ Sun Tzu mengabdi kepada raja Ho-lu

5. Fu Yu Lang, Short History of Chines Philosophy (yogyakarta: Pustaka Pelajar, 2007), 3 .. 
dari $\mathrm{Wu}$. Dengan menjabat panglima perang $\mathrm{Wu}$, dia dapat menaklukkan Ch'i dan Chin. Sejak itu namanya menjadi terkenal.

Oleh karena itu, Sun Tzu bukanlah nama asli, melainkan sebuah sebutan kehormatan seperti halnya Kong Tzu (Konfusius) atau Lao Tzu (Lao Tse). Dalam budaya Tiongkok Sun Tzu tidak jauh dari Sun Ztu Bingfa (Hanyu Pinyin: Sūnž̆ Bīngfă), atau dikenal pula sebagai Sun Tzu Art of War, Sun Tzu juga dikenal sebagai seorang Jenderal Ahli Siasat perang yang hidup sekitar abad ke-6 oleh Sun Tzu'6.

Sun Tzu juga memiliki kitab militer, ketika pertama kali memperlihatkan kitab militernya kepada raja Ho-lu, ia ditanya apakah kitab tersebut dapat digunakan dalam segala medan dan oleh siapa saja. Dia menjawab, "Dapat." Keberhasilan strateginya diperlihatkan di dalam kemampuannya melatih 180 wanita penghibur istana menjadi tentara yang handal hanya dalam sekali latihan saja.

Kitab militer Sun Tzu mulai dikenal kalangan barat ketika sebelum masa Revolusi Prancis, seorang pendeta Prancis berhasil menerjemahkan kitab itu. Di Amerika sendiri, Henry Kissinger adalah seseorang yang sering menerapkan strateginya. Saat ini, kitab militer Sun Tzu tidak saja diaplikasikan dalam militer, namun juga bisnis, olah raga, diplomasi maupun bisa diterapkan di dalam kehidupan pribadi. Namun sayang, tidak banyak catatan sejarah yang dapat mengungkap lebih detail mengenai kehidupan Sun Tzu beserta bagaimana ia wafat, apakah di masa damai atau dalam pertempuran.

Karya ini merupakan karya tulis militer Tiongkok yang paling dihormati dan paling terkenal di luar negeri Tiongkok. Siapa yang menulis buku ini sampai sekarang masih diperdebatkan oleh para pakar sejarah. Beberapa ahli berpendapat bahwa Sun Tzu bukanlah nama asli penulis buku ini, melainkan julukan yang diberikan orang kepada penulis tersebut. Sebab, kata "Tzu" pada nama Sun Tzu

6. Sulistiyo, "Antara Seni Berperang Ala Sun Tzu, Akuntansi Dan Sustainabilitas Organisasi." 
sebenarnya digunakan untuk mengacu pada seorang filsuf sehingga Sun Tzu diartikan sebagai "filosuf Sun."

\section{Strategi Perang Sun Tzu}

Kata "strategi" pada mulanya sangat akrab di kalangan militer, secara etimologis berasal dari kata majemuk bahasa yunani, yaitu strategos yang berarti pasukan dan agein yang berarti memimpin, secara umum kata strategi yang dipergunakan dikalangan militer sering diartikan sebagai seni memenangkan perang melawan musuh dengan pemanfaatan kekuatan yang dimiliki secara maksimal. Strategi perang yang dilaksanakan suatu negara sangat bervariasi hal banyak faktor yang mempengaruhi seperti geografi, potensi nasional, dan lain sebagainya. Semua faktor tersebut disebut sebagai sarana untuk mencapai tujuan.

Sun Tzu atau "Guru Sun" adalah orang yang terkenal dengan karya besar klasik dalam dunia militer, yang terkenal dengan strategi perangnya dalam sejarah peradaban Tiongkok. Dan sekarang digunakan dunia untuk strategi ekonomi dan ini dibuktikan dengan perubahan perang, dari seni terhormat menjadi industri. ini dilihat dalam sejarah fenomena perang dingin sebagai mana diketahui, wajah dunia dalam 40 tahun perang (1950-1991) yang terpolarisasi dengan dua blok, hal ini memicu konflik baru pada peradaban berupa ekonomi sebagai bentuk fenomena persaingan dengan wujud seni perang yang baru dalam satu strategi yang sama berupa metode atau strategi Sun $\mathrm{Tzu}^{7}$.

Begitu pentingnya sebuah strategi terutama perencanaan, sehingga Sun Tzu meletakkan penyusunan rencana dalam bab pertama karyanya itu. Judul aslinya adalah she chi bien, yang dapat diartikan Bab Menyusun Rencana. Sun Tzu mengatakan, setidaknya ada 5 faktor yang harus dikuasai sebagai dasar dalam menyusun rencana perang.

7. Rogert Arnes, The Art of War (Batam: Lucy Publisher, 2002), 149. 


\section{Tao, Thien, Tie, Ciang, dan Fak.}

Maksud dari kalimat di atas adalah sebagai berikut;

1. Tao, faktor moral. Jika pemimpin negara mendapat dukungan moral dari rakyat, maka rakyatnya pasti siap bertempur dan akan rela berkorban.

2. Thien, faktor langit. Menyangkut cuaca, musim, gelapterang, peluang.

3. Tie, faktor geografi, jarak, dan terjalnya medan pertempuran.

4. Ciang, faktor kepemimpinan. Menyangkut wibawa dan kharisma seorang pemimpin yang bijak dan tegas.

5. Fak, faktor hukum, kedisiplinan, serta struktur organisasi yang rapi dan solid.

Jika 5 faktor ini dikuasai, ditambah pertimbangan faktor pendukung lainnya, maka, pemimpin negara akan mampu menyusun rencana perang dan strategi yang sangat efektif dan efisien. Sun Tzu menegaskan: Barang siapa mampu menyusun rencana dengan sangat seksama, akurat, dan detail, dia akan memenangkan peperangan. Sebaliknya, barang siapa gegabah dan tidak fokus dalam perencanaan, mustahil dia menang perang. Jadi, dari cara menyusun rencana saja, sudah dapat diramalkan, seseorang akan meraih kemenangan, atau akan dikalahkan lawan, Pada 2400 tahun yang lalu, Sun Tzu sudah punya pola pikir dan daya analisis yang sangat strategis.

Sun Tzu mengingatkan, kemenangan bisa direngkuh melalui penyusunan rencana strategi yang matang. Jangan sekali-kali bertindak gegabah atau sembrono pada tahap yang paling mendasar ini. Adakan penyelidikan, pengumpulan data atau informasi yang lengkap, akurat, detail, menyeluruh, serta tinggi tingkat presisinya. Kemudian, analisis dengan tajam berbagai faktor di lapangan. Hasilnya, strategi perang yang tidak saja efektif, tetapi juga lebih berdaya guna. 
Di dunia marketing, seni perang Sun Tzu menjiwai konsep modern analisis SWOT. Seseorang pasti sangat mengenal konsep yang menekankan pentingnya analisis Strength atau Kekuatan, Weakness atau Kelemahan, Opportunity atau Kesempatan, dan Threath atau Ancaman. Berpuluh-puluh tahun lamanya, analisis SWOT ini telah dibuktikan keandalannya oleh para marketer.

Contoh: jika seseorang ingin melakukan dakwah. Sebelumnya harus ada analisis audience, sehingga dalam menyampaikan tema dapat diterima oleh masyarakat. Analisis tersebut diantaranya adalah identifikasi keadaan alam, sikap penduduk terhadap lingkungan, kependudukan, kebudayaan, ketenagaan, dan kelembagaan ${ }^{8}$.

\section{Puk Che Chi Pu Che Bie Pai Chan Pik Pai.}

Artinya, tidak mengenal kekuatan dan kelemahan diri sendiri. Tidak mengenal kekuatan dan kelemahan musuh. Maka, 100 kali bertempur 100 kali akan kalah. Baik di Indonesia maupun mancanegara, tak satu pun materi dapat diterima dengan baik tanpa perencanaan dan strategi marketing yang matang. Jadi supaya menang kompetisi dan survive, gunakan kekuatan strategi perang Sun Tzu.

\section{Kiat-Kiat Meraih Sukses Menurut Sun Tzu}

Kiat-kiat meraih sukses yang diajarkan oleh Sun Tzu cukup bisa dijadikan sebagai pertimbangan dalam meraih sukses diantaranya adalah sebagai berikut:

\section{Kordinasikan Taktik Dengan Strategi}

Dalam hierarki manapun, strategi disatu tingkatan akan sering menjadi taktik ditingkatan berikutnya. Demikianlah rencana utama itu menjadi semakin terfokus, sementara tindakan dilaksanakan secara

\footnotetext{
8 Direktorat Penerangan Agama Islam, Buku Penunjang Tugas Penyuluh Agama: Manajemen Dakwah (Dasar-Dasar Dakwah/Penyuluh Agama Islam) (Jakarta: Kementerian Agama RI Direktorat Jenderal Bimbingan Masyarakat Islam, 2011), 9.
} 
berjenjang di sebuah organisasi. Strategi dan taktik harus disatukan. Ketika dipisahkan antara perencanaan dan pelaksanaan, itu sama saja dengan memisahkan berpikir dan berbuat, dan tanggung jawab pun menjadi tidak jelas lagi.

Terkait dengan strategi menarik sekali menyimak cerita dari Fransisca Pizarro ketika mengkordinasikan strategi dengan taktik mengkordinasikan pasukannya ketika menaklukan kekaisaran Inca dengan empat lusin kuda dan beberapa ratus orang.

Ide kunci yang mendefinisikan dalam Sun Tzu: seni perang adalah shih yang diterjemahkan secara konsisten sebagai "keunggulan strategis", ini adalah gagasan yang rumit yang unik dalam tradisi Tiongkok, dan menolak terjemahan perumusan yang sederhana. Malah, pemahaman akan shih bukan saja mengharuskan diadakannya pembandingan diantara berbagai arti yang mungkin, melainkan juga menuntut pengenalan dengan asumsi-asumsi yang dijelaskan, yang menjadikan cara pandang Tiongkok klasik begitu berbeda dibandingkan dengan cara pandang kebanyakan masyarakat.

Perbedaan antara keunggulan strategi (shih) dengan pengambilan posisi strategis (hsing). Seperti yang telah ditunjukan oleh D.C. Lau, dalam Sun Tzu ada kisah-kisah di mana kedua istilah ini hampir sebagai persamaan kata. Ini dikarenakan shih tumpang tindih dengan hsing dalam konotasi posisi fisik buka posisi sebagai lokasi spesifik, melainkan sebagai disposisi yang berubah-ubah, yang selalu tanggap terhadap konteks.

Artinya hsing terbatas pada bentuk berwujud serta pasti dari kekuatan fisik, shih menyangkup hal-hal yang tak berwujud seperti moral, peluang, waktu, psikologi, dan logistic. Pengambilan posisi strategis (hsing) yang efektif menciptakan situasi di mana kita dapat menggunakan "keseluruhan yang tak terbagi untuk menyerang yang satu", memikul beban seratus ketimbang beberapa ons, dan menggunakan yang banyak untuk menyerang yang sedikit yaitu, memenangkan perang sebelum bertempur. 


\section{Bergerak Dengan Cepat}

Kecepatan adalah inti perang, Yang dihargai dalam perang adalah Kemenangan yang cepat diraih, bukan oprasi berkepanjangan

Sun Tzu

Kecepatan adalah inti perang dan meraih kemenangan. Jendral Patton menyatakan bahwa rencana baru separuh dikembangkan tetapi dilaksanakan dengan sepenuh hati adalah lebih baik dari pada rencana sempurna yang terlambat dilaksanakan, terlalu sering, yang menghambat kemajuan adalah tidak adanya rasa mendesak. Masalahnya bukanlah sekedar "melaksanakannya" dengan cepat, melainkan juga memutuskan untuk melaksanakannya sama sekali.

\section{Meraih Momentum}

Ketika air yang deras melemparkan batu-batuan,

Itu adalah berkat momentum,

Energinya serupa dengan busur yang ditarik maksimal.

Momentum seseorang yang terampil dalam perang sungguh luar biasa

_Sun Tzu

Serangan itu harus merupakan proses yang kontinu. Ketika seseorang meraih momentum, peluang untuk mengambil keputusankeputusan yang tepat untuk jangka panjang. Tidaklah sulit dipahami bahwa setiap tindakan yang positif atau tingkat sukses yang positif menghasilkan emosi yang positif. Clausewitz mengatakan bahwa upaya lanjutannya adalah sama pentingnya dengan serangannya. Teruslah bergerak.

Pengambilan keputusan yang cepat menghasilkan pelaksanaan yang cepat

Semakin singkat waktu pengambilan keputusannya, semakin cepatlah suatu keputusan dapat dikomunikasikan. Ini memungkinkan segalanya berlangsung lebih cepat dan menuntun kepada kemungkinan sukses yang lebih besar. Sebaliknya, keputusan- 
keputusan yang ditunda-tunda pasti kehilangan kualitas positifnya. Kalau seseorang menunda terlalu momentum, lawan-lawannya akan mempunyai waktu untuk bersiap-bersiap dan teman-teman akan kehilangan kesabaran.

Aksi yang cepat adalah aksi yang sekaligus.

Ketika kelancaran itu maksimal, lebih mudah mengkordinasikan semua aksi menjadi aksi sekaligus.

\section{Memanfaatkan Peluang yang Ada}

Seorang komandan yang terampil meraih skor yang tinggi dengan

Dengan memanfaatkan situasi yang ada dengan sebaik-baiknya.

__Sun Tzu

Kunci menuju persamaan manapun yang sukses adalah mengambil langkah sukses yang pertama lalu mengukir sukses tambahan dari setiap kemenangan baru. Efek mungkin berisi tunggal menghasilkan tekanan yang menghancurkan hubungan-hubungan. Orang yang memberikan efek mungkin tidak mendapatkan apa-apa sebagai balasannya.

\section{Mengimplementasikan Strategi Seni Perang Sun Tzu terhadap Manajemen Dakwah dalam Pengembangan Masyarakat}

Implementasi Ajaran-Ajaran Sun Tzu yang dapat diterapkan terhadap manajemen dakwah adalah sebagai berikut

\section{Prinsip mengenali diri sendiri (identifikasi kepribadian)}

Kenalilah musuh dan kenalilah diri sendiri,

Maka anda bisa bertempur ratusan kali tanpa terancam kalah.

Kalau tidak mengenal musuh ataupun diri sendiri,

Anda pasti kalah dalam setiap pertempuran.

_Sun Tzu

Pernyataan Sun Tzu di atas merupakan prinsip dasar seseorang dalam menggapai kesuksesan dalam hidup. Tidak ada seorangpun yang bisa memberitahu siapa sesungguhnya dia; semua orang bisa 
membantu dalam upaya mencari tahu dia. Masalahnya terletak bukan saja dalam persepsi seseorang tersebut, melainkan dalam keyakinan. Semakin akurat seseorang memahami kekuatan-kekuatan serta kelemahannya, maka semakin efektiflah seseorang tersebut dalam segala upayanya ${ }^{9}$.

Kemampuan seseorang untuk mengidentifikasikan diri sendiri menjadi jelas lewat tes kepribadian yang digunakan secara luas. Dalam proses ini, para partisipan diminta memilih prefensi masingmasing dalam empat kategori sebelum menyelesaikan sebuah kuesioner yang otomatis mengukur prefensi mereka dan tipe kepribadian mereka. Semakin seseorang mengenali dirinya sendiri dan alasan prefensi serta perbuatannya, maka dia semakin mengenal orang lain. Pengenalan diri tersebut melahirkan alam semesta pengetahuan tentang dinamika manusia ${ }^{10}$.

Perlu diperhatikan di sini petuah Sun Tzu yang sangat terkenal: "Kenalilah musuhmu dan kenalilah dirimu, niscaya Anda akan berjaya dalam ratusan pertempuran." Agar bisa tahu dan mengeksploitasi kelemahan pesaing-pesaing di dalam berbisnis, butuh pemahaman mendalam tentang strategi, kapabilitas (kesanggupan), pemikiran, seperti juga pengetahuan yang dalam atas kekuatan dan kelemahan masyarakat. Penting juga untuk mengerti keseluruhan persaingan serta tren yang terjadi di sekeliling.

Di sisi lain, dalam membuat perencanaan berarti mengadakan suatu perhitungan agar dapat menjalankan suatu rencana yang praktis, harus mengulang-ngulang hitungannya beberapa kali. Hasil pertempuran akan memberikan sisi keuntungan dan kerugian. Kedua sisi ini, harus diperhatikan. Dalam strategi serangan dikatakan Sun Tzu, "Kenalilah musuh dari diri anda", maka anda akan bisa masuk ke dalam ratusan pertarungan tanpa bahaya kekalahan, Jika anda

${ }^{9}$ Gerald Michaelson, Kiat Sun Tzu Meraih Sukses (Batam: Karisme Press, 2008), 80.

${ }^{10}$ Michaelson, Kiat Sun Tzu Meraih Sukses. 
mengenal salah satu kelemahan daripada musuh anda, kesempatan menang tetap ada pada perusahaan anda. Konsep Pertempuran Sun Tzu untuk mengenali musuhmu itu dapat diintrepetasikan ke dalam sebagai perilaku analisis kompetetitif, yang dalam praktiknya terdiri dari memahami komptetitor, memahami produk dan memahami layanan. ${ }^{11}$

Pada aspek perencanaan manajemen dakwah dalam pemberdayaan masyarakat harus diketahui materi yang bisa memenuhi keinginan masyarakat, untuk melihat keinginan tersebut, maka kenalilah faktor-faktor yang diminati masyarakat. Sehingga kita bisa mempersiapkan materi dan pelayanan yang bisa ditawarkan kepada masyarakat. Setelah itu, barulah membuat menyampaikan materi yang dibutuhkan masyarakat.

Dalam mengenali diri sendiri, masyarakat harus kepercayaan diri yang tinggi dan tidak mudah menyerah dalam perbaikan diri. Sebaliknya, seseorang tidak boleh sombong, ketika meraih kesuksesan di dalam kehidupan, ketika kita sukses harus mengembangkan diri untuk terus berkarya. Kesombongan itu akan mengaburkan seseorang untuk mengetahui kekuatan dan kelemahan sendiri dan lawan. Pengenalan pesaing diharapkan dapat membantu untuk menentukan strategi yang dipakai. Untuk mengenal medan atau pasar diperlukan pengalaman di lapangan. Dengan mengenal medan, seseorang akan mampu terus berinovasi dan menciptakan momentum. Melainkan juga, dengan memahami diri sendiri, dan lawan musuh sebagai pesaing kita akan mampu untuk meraih kesuksesan di dalam berbisnis.

Sekali lagi, menurut Sun Tzu jika tidak ada kepastian untuk menang atau membuka usaha atau bisnis, janganlah merencanakan serangan. Dalam manajemen dakwah untuk menjadi tak terkalahkan

\footnotetext{
11 Ulfa Fawzia and Baiq Wardhani, "The Identification of 'The Art of War' Military Strategy On Netflix's Business Strategy," Global Strategis 14, no. 1 (2020): 147.
} 
maka kita harus merencanakan pendesainan materi, cara menyampaikan materi, dan bertemu dengan pelanggan dan sesama profesi pendakwah.

\section{Integritas Moral}

Komandan yang handal dalam perang meningkatkan

Pengaruh moral dan patuh kepada hukum serta peraturan.

Demikianlah, ia berkuasa mengendalikan sukses.

Sun Tzu

Moralitas berasal dari bahasa latin "mos" (tunggal ), "mores" (Jama'). Bentuk jama' "mores" berarti kebiasaan, kelakuan, kesusilaan. Kata sifat "moralis" berarti susila. ${ }^{12}$ Berbicara tentang moral, bukan hanya apa yang biasa dilakukan orang, melainkan juga apa yang menjadi pemikiran dan pendirian mengenai apa yang baik dan apa yang tidak baik, patut dan tidak patut untuk dilakukan secara sadar (actus humanus).

Immanuel Kant (1724-1804) berpendapat bahwa nilai moral diperoleh di dalam moralitas dan moralitas adalah kesesuaian sikap dan perbuatan dengan norma atau hukum batiniah, yakni apa yang dipandang sebagai kewajiban. Moralitas akan tercapai apabila menaati hukum lahiriah bukan lantaran hal itu membawa akibat yang menguntungkan atau lantaran takut kepada penguasa sang pemberi hukum, melainkan manusia seorang menyadari bahwa hukum itu merupakan kewajiban, atau bertindak demi kewajiban itu sendiri.

Kekuatan pengaruh moral merupakan inti dari kemampuan Sun Tzu untuk memimpin pasukan. Integritas moral merupakan karakteristik pemimpin-pemimpin yang sukses di dalam berbisnis. Dengan memiliki moral, dalam konteks manajemen dakwah dan pemerdayaan masyarakat, yakni menghormati audience/maudhu/masyarakat kelompok sasaran, menggunakan komunikasi yang baik di dalam berdakwah, serta membangun sikap

12. K. Bertens, Etika (yogyakarta: Kanisius, 2002), 4. 
kejujuran di dalam berdakwah ini akan memberikan efek yang positif untuk meraih sukses di dalam berdakwah dan pemberdayaan masyarakat.

Integritas adalah landasan dari reputasi pribadi. Reputasi pribadi adalah didasarkan pada persepsi orang lain tentang prilaku seseorang. Dasar integritas yang kuat memberi seseorang daya mungkin untuk membangun reputasi dan melaksanakan rencana untuk meraih sukses pribadi. Oleh karenanya integritas moral merupakan salah satu kunci sukses seseorang dalam menggapai kehidupannya.

\section{Sikap berani}

Prinsip kepengurusan militer adalah meraih

Tingkat keberanian yang merata _Sun Tzu

Kepentingan Sun Tzu dalam pernyataan di atas adalah membuat orang-orangnya berani bertempur. Seseorang membutuhkan keberanian dalam pergelutannya sehari-hari. Segala sesuatu yang diperbuat pasti ada resikonya, tidak berbuat apa-apa juga ada resikonya. Sesungguhnya, berusaha mempertahankan status quo bisa menjadi resiko yang terbesar ${ }^{13}$.

Orang yang mengambil resiko dan mengambil tindakan jarang sekali mengklaim dirinya berani, Mereka "sekedar melakukan apa yang tentu apa yang dilakukan siapa pun" dalam situasi tersebut. Mereka tidak mengakui mempunyai ambisi seumur hidup untuk bersikap berani. Ketika dibutuhkan dorongan mereka mungkin mengatakan sesuatu yang seperti "saya tidak mikir dua kali" atau "habis, hanya itu yang bisa saya perbuat". Mereka hanya melakukan apa yang mereka rasa perlu dilakukan.

Kepercayaan diri adalah induknya keberanian mengambil tindakan untuk melakukan hal yang benar. Diambil tindakan bukan

${ }^{13}$ Michaelson, Kiat Sun Tzu Meraih Sukses. 
hanya karena dorongan yang didasarkan pada nilai-nilai melainkan juga karena pendidikannya memberi keyakinan bahwa seseorang bisa meraih sukses atau secara mental merasa puas bahwa seseorang "telah berupaya sebaik-baiknya".

Di sisi lain, kepercayaan itu boleh saja asal mempunyai landasan yang mantap. Sementara tidak adanya kepercayaan diri merupakan ujung yang ekstrim pada skalanya, terlalu percaya diri pun merupakan ujung ekstrim lainnya yang sama mematikan. Terlalu percaya diri menciptakan situasi-situasi di mana seseorang akan dikalahkan oleh sesuatu yang tidak disangka-sangka. Ketika seseorang yakin segalanya berjalan dengan baik, itu bisa jadi menjadi bumerang pada sosok seorang tersebut. Kepercayaan diri pada fisik melibatkan tubuh, kepercayaan diri pada mental melibatkan mental. Dalam banyak kasus, kepercayaan diri pada tubuh dan mental saling mengaitkan.

Kepercayaan diri dalam artian tidak terlalu berlebihan dan memilki keberaniaan mengambil resiko di dalam berdakwah dan pemberdayaan masyarakat ialah kunci sukses untuk mencapai keberhasilan dakwah. Itulah ide-ide pokok yang ditawarkan Sun Tzu dalam dakwah dan pemberdayaan dengan menggunakan strategi perang.

\section{Disiplin}

Kalau disiplin tidak ditegakkan,

Anda tidak mungkin mengerahkan pasukan.

Beberapa bagian dari The Art of War yang paling terkenal menyarankan untuk berdisiplin yang kuat. Kisah tentang "para selir" mendemonstrasikan bagaimana Sun Tzu menggunakan disiplin untuk meraih prestasi dan meraih sukses di dalam berdagang maupun berbisnis. Penekanan terhadap disiplin ini konsisten dengan para juara yang berada di mana-mana. Segala prestasi besar dicapai lewat 
disiplin. Bangsa Jepang mempunyai kata disiplin untuk membangun kembali sebuah proses yaitu Keizen yang berarti peningkatan terus menerus. Keizen, sebagai disiplin juga mempunyai tempat dalam peningkatan pribadi. ${ }^{14}$

Disiplin diibaratkan sebagai sahabat bukan musuh. Alasan untuk tidak melatih disiplin yang baik itulah musuh yang sesungguhnya. Disiplin membuat seseorang terus melakukan hal yang benar dan menempatkannya di jalan menuju target yang dituju. Disiplin adalah bangun pagi-pagi untuk mempelajari bagaimana seseorang meningkatkan profesinya, atau berolahraga untuk meningkatkan kesehatan fisiknya. Pagi adalah waktu yang paling baik untuk melatih disiplin sebab menundanya pada siang hari berarti itu bisa ditunda hingga besok dan lusa, tanpa konsistensi tidak ada disiplin.

Di sisi lain, disiplin ini juga diinterpretasikan bagaimana seorang pimpinan organisasi dakwah harus memberikan pelajaran dan pengarahan kepada bawahannya supaya dalam bekerja itu datang tepat waktu, sehingga dengan dispilin bekerja itu akan memberikan keutungan dan sumbangsih meraih kesuksesan. Pepatah mengatakan "time is money".

Sun Tzu mengatakan, "jadikanlah waktu itu sekutu anda", ini berarti menjadikan waktu bisa berguna secara efektif dan efisien secara cepat, Bagi Sun Tzu waktu itu memiliki nilai yang berharga. Ada beberapa persoalan kunci dalam menjadikan waktu itu sebagai sekutu anda. Pertama, sebagai aturan, paling dini itu paling baik, waktu yang dihemat sama dengan waktu yang diraih. Kedua, semakin lama anda mulai, semakin banyak yang anda butuhkan. Ketiga, semakin mendesak kebutuhan untuk mengambil keputusan, semakin lama waktu yang dibutuhkan. Keempat, tindakan yang cepat, adalah tindakan yang akan meraih keuntungan.

${ }^{14}$ Michaelson. 
Kedisiplinan waktu yang berhubungan dengan efisien dan efektif itu bila dilihat dengan kacamata etika, ternyata disebut juga dengan etika utilitarianisme evolusioner. Spinoza mengatakan, menjadi baik artinya melakukan aktivitas tertentu di mana anda beritindak efisien, jadi dispilin waktu adalah sebuah etika yang perlu dikedepankan ${ }^{15}$.

\section{Bersikap Penuh pertimbangan}

Perhatikanlah kesejahteraan para prajurit dan

Janganlah mereka menjadikan mereka kelelahan

_Sun Tzu

Kata-kata Sun Tzu di atas itu, memberikan suatu ilmu dan pengetahuan baru ketika kita ingin melakukan dakwah dan pemberdayaan masyarakat. Pada dasarnya, seorang pimpinan lembaga dakwah harus juga memberikan perhatian kesejahteraan terhadap karyawannya dan masyarakat. Sehingga kalau bisa pengusaha harus mampu memberikan yang terbaik dalam artian kesejahteraan karyawab dan masyarakat dapat terjamin.

Selain itu, dengan memberikan pelayanan atau tunjangan terhadap karyawan ini akan memberikan dan menciptakana kesadaran untuk meningkatkan kerja dan melalui pertimbangan gaji dan kesejahteraan itu, seorang karyawan merasa diperlakukan dengan baik, sehingga kebaikan seorang pengusaha bisa saling membantu dengan karyawan.

Namun demikian, kalau bisa seorang pimpinan lembaga bisa langung memberikan gaji sebelum karyawan itu kering keringatnya, jangan sampai karyawan itu meminta gaji kepada bos, atau direktur perusahaaan. Akan tetapi, ketepatan waktu dalam memberikan gaji juga akan membantu lembaga dakwah meraih sukses jauh lebih besar.

15. D. Milton Hunnex, Peta Filsafat: Pendekatan Kronologis Dan Tematis (Bandung: Penerbit Teraju, 2004), 61. 
Di sisi lain, kelicikan dalam semua pekerjaan menyebabkan kegagalan, sedangkan kecerobohan melakukan pekerjaan sebelum dipertimbangkan secara mendalam, merupakan sebab ketidakberhasilan pula. Seperti disaksikan sekelompok orang yang bersemangat bekerja mengurus berbagai persoalan, tetapi tidak lama kemudian mereka kembali tanpa membawa hasil alias rugi. Mereka gagal dalam pekerjaan yang telah mereka kerjakan tanpa adanya pertimbangan dulu. Tidak lama cita-cita mereka yang direncanakan tanpa pertimbangan itu gagal.

Sesungguhnya pesan dari realitas kejadian tersebut jelas dan tampak bagi setiap orang yang berpikir. Sebenarnya setiap pekerjaan dari berbagai pekerjaan itu, diantaranya adanya kemungkinan bisa mencapai keberhasilan dan ada juga menuai kegagalan. Sedangkan orang yang berakal adalah orang yang selalu mempertimbangkan pekerjaan yang akan dikerjakan sebelum menanganinya. Apabila dia melihat, bahwa pekerjaan itu dapat diupayakan berhasil, maka dia memusatkan perhatiannya pada pekerjaan itu, lalu memualai mengerjakannya dengan semangat. Tetapi, apabila dia memperhitungkan, bahwa pekerjaan yang akan ditanganinya tidak membawa hasil, maka dia tidak mau menyiakan waktu terbuang siasia dalam mengerjakannya.

Sun Tzu berkata: "hargailah orang-orang seperti bunyi, maka ia akan berjalan-jalan dengan kamu sampai bukit yang paling dalam, anggaplah prajuritmu sebagai anak yang kamu kasihi, maka ia akan bersedia mati anda". Seorang pimpinan lembaga dakwah harus bisa menunjukkan kepada karyawannya cara bekerja saling pengertiaan dalam duka dan suka. Berikanlah sesuatu penghargaan kepada pekerja atau karyawan. Dalam dunia dakwah ini berarti, kita harus menghargai mereka yang telah banyak memberikan sumbangsih tenaga dan pikiran di dalam perusahaan.

Berpijak dari hal itu, memberikan kesejahteraan dan penghargaan terhadap karyawan adalah-meminjam analisis St Paul, 
sebagai bagian dari etika kasih. ${ }^{16}$ Sikap itu timbul dari kewajiban hati nurani untuk saling mengasihi dan memberikan kesejahteraan kepada para karyawan karena telah bekerja di dalam lembaga dakwah.

\section{SIMPULAN}

Pada intinya, pemikiran Sun Tzu mengenai manajemen dan strategi perang bisnis, ternyata memberikan banyak inspirasi-inspirasi yang sangat filosofis dan bijak di dalam kita melakukan dakwah dan pemberdayaan terhadap kelompok sasaran masyarakat.

Ajaran Sun Tzu yang baik dan sangat menonjol ialah kenalilah musuh dan kenalilah diri sendiri. Sehingga dengan mengenal musuh atau pesaing dalam berdakwah dan pemberdayaan masyarakat, kita harus mampu melakukan pembacaan dan pengamatan terhadap kondisi riil lawan kita dalam berdakwah dan pemberdayaan masyarakat sehingga bisa mengetahui kelemahan dan kekurangan yang dimiliki lawan. Melainkan juga, dengan mengenal kemampuan diri sendiri, berarti kita mengetahui kekuatan kita sendiri bagaimana cara melawan musuh dengan jalan yang baik.

Sementara itu, kekuatan moral, dalam artian menanamkan integritas dalam sistem manajemen dakwah atau dengan mengembangkan sikap kejujuran dan komunikasi yang baik juga akan membantu meraih kesuksesan dalam berdakwah dan memperdayakan masyarakat.

Di sisi lain, sikap berani dalam mengambil resiko, merupakan modal awal menuju keberhasilan. Berdakwah dan pemberdayaan masyarakat jelas harus berani menghadapi sebuah resiko. Sedangkan, dengan mengedepankan sikap dispiln dalam bekerja, akan membantu dalam proses untuk meraih keuntungan dalam berdakwah dan pemberdayaan masyarakat

Namun demikian, ada faktor yang paling signifikan dalam berdakwah, yakni seorang dai atau pimpinan lembaga dakwah juga

16. Hunnex, Peta Filsafat: Pendekatan Kronologis Dan Tematis. 
harus memberikan kesejahteraan terhadap karyawan dengan menambah gaji atau memberikan gaji tunjangan. Di samping itu, juga memberikan fasilitas dan sarana yang baik, sehingga para karyawan ini merasa nyaman di dalam melakukan sebuah pekerjaan. Karena itu, pemikiran Sun Tzu melalui ajaran-ajarannya manajemen perang bisnis itu sangat membantu seorang pendakwah dalam menjalankan suatu lembaga dakwah dalam melaksanakan pemberdayaan masyarakat. dakwah dan pemberdayaan masyarakat melalui strategi perang itu perlu diimplementasikan terhadap pendakwah dan lembaga dakwah di Indonesia.

\section{DAFTAR PUSTAKA}

Arnes, Rogert. The Art of War. Batam: Lucy Publisher, 2002.

Bertens, K. Etika. yogyakarta: Kanisius, 2002.

Creel, H.G. Chinese Thought from Confusius to Mao Tse-Tung. Yogyakarta: Tiara Wacana, 1990.

Fawzia, Ulfa, and Baiq Wardhani. "The Identification of "The Art of War' Military Strategy On Netflix's Business Strategy." Global Strategis 14, no. 1 (2020): 143-60.

Hunnex, D. Milton. Peta Filsafat: Pendekatan Kronologis Dan Tematis. Bandung: Penerbit Teraju, 2004.

Islam, Direktorat Penerangan Agama. Buku Penunjang Tugas Penyuluh Agama: Manajemen Dakwah (Dasar-Dasar Dakwah/Penyuluh Agama Islam). Jakarta: Kementerian Agama RI Direktorat Jenderal Bimbingan Masyarakat Islam, 2011.

Kartika, Arista Fauzi. "FINANCIAL ENGINEERING: Win-Win Solution 'Sun Tzu' Untuk Jaminan Pada Akad Mudharabah." Jurnal Penelitian Teori \& Terapan Akuntansi (PETA) 2, no. 2 (2017): 98-111.

Lang, Fu Yu. Short History of Chines Philosophy. yogyakarta: Pustaka Pelajar, 2007.

Michaelson, Gerald. Kiat Sun Tzu Meraih Sukses. Batam: Karisme Press, 
2008.

Suastama, Ida Bagus Radendra. "Seni Perang Sun Tzu Tentang Strategi Operasi Dikaitkan Dengan Manajemen Bisnis." In Forum Manajemen STIMI Handayani Denpasar, 9:72-75, 2011.

Sulistiyo, Agung Budi. "Antara Seni Berperang Ala Sun Tzu, Akuntansi Dan Sustainabilitas Organisasi." EKUITAS (Jurnal Ekonomi Dan Keuangan) 16, no. 1 (2018): 16-31. 